\title{
EXTRACTION OF BARU ALMOND OIL USING ALTERNATIVE SOLVENTS TO HEXANE: ETHANOL AND ISOPROPANOL
}

Ana Luísa S. Souza ${ }^{1 凶(i)}$, Julia S. Miranda ${ }^{1 凶(D)}$, Rita C. S. Sousa ${ }^{* 1}$ (iD, Bruno B. Vieira ${ }^{1}$ (iD, Jane S. R. Coimbra 2 (iD)

${ }^{* 1}$ Department of Chemistry, Universidade Federal de Viçosa, Brazil

2 Department of Food Technology, Universidade Federal de Viçosa, Brazil

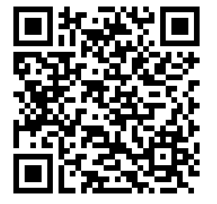

DOI: https://doi.org/10.29121/granthaalayah.v8.i8.2020.1197

Article Type: Research Article

Article Citation: Ana Luísa S. Souza, Julia S. Miranda, Rita C. S. Sousa, Bruno B. Vieira, and Jane S. R. Coimbra. (2020). EXTRACTION OF BARU ALMOND OIL USING ALTERNATIVE SOLVENTS TO HEXANE: ETHANOL AND ISOPROPANOL. International Journal of Research GRANTHAALAYAH, 8(8), 356-371. https://doi.org/10.29121/granthaa layah.v8.i8.2020.1197

Received Date: 17 August 2020

Accepted Date: 31 August 2020

Keywords:

Kinetic Extraction

Optimization

Batch

Response Surface Methodology

\section{ABSTRACT}

The baru oil has a high degree of unsaturation and relevant amount of oleic and linoleic acids content, which favors its use for food and pharmaceutical industries. Hexane is the most widely used solvent for oil extraction. However, its flammability, cost, and polluting potential justify the study of alternatives solvents such as ethanol and isopropanol that are less toxic and flammable and efficient in the extraction of other oils, as already reported in literature. This work represents the extraction of baru almond oil with the solvents hexane, ethanol, isopropanol, and isopropanol: ethanol (1:1) to compare their extraction yields. The parameters solid: solvent ratio, temperature and time were optimized using a central composite design. The higher yields were found in lower solid: solvent ratios and higher temperatures (ethanol - $29.12 \%$, isopropanol - $39.66 \%$, isopropanol: ethanol - $41.13 \%$ and hexane - 36.59 $\%)$. Isopropanol and isopropanol: ethanol (1:1) mixture presented satisfactory results when compared to hexane, becoming alternatives for its replacement. In the extractions which the time was significant, the adjustment of the kinetic models indicated that the extraction is described by a second order model. The solvents researched showed to be promising for hexane replacement in the oil extraction from baru almond.

\section{INTRODUCTION}

Brazil presents several biomes known for their high biodiversity, with unique native species, which have been increasingly studied and investigated, among them, Cerrado stands out [1]. The barueiro (Dipteryx alata vog.) belonging to the Fabaceae family, is one of the native species of great importance in Cerrado. This plant has as fruit the baru, whose pulp involves an edible almond [2].

Recent research indicates that the daily consumption of oilseeds contributes to a reduction in the incidence of chronic non-communicable diseases due to the presence of biologically active compounds [3], [4]. Baru almond oil can contribute to the sustainability of the population of the Brazilian cerrado but is still little produced in Brazil [5].

According to proximate food composition studies of baru almonds, lipid percentages found were between 39.7 $\%$ and $43.7 \%$ [1], [6] predominantly composed of oleic acid (50 - $54 \%$ ) and linoleic acid (23 - $25 \%$ ) [7]. Besides

(C) 2020 The Author(s). This is an open access article distributed under the terms of the Creative Commons Attribution License, which permits unrestricted use, distribution, and reproduction in any medium, provided the original author and source are credited. 
having a high energy value, the baru almond is rich in zinc, an important mineral for female and male fertility, improving the production of the hormones [8].

Baru almond oil has a high degree of unsaturation, and its lipid fraction has, mostly, oleic and linoleic acids. Schincaglia et al. [9] reported that baru almond oil supplementation may improve ultra-sensitive C-reactive protein concentration in hemodialysis patients with chronic kidney disease. According to Marques et al. [10], the chemical composition of baru oil offers an economic potential in the food, pharmaceutical and cosmetic industries.

Traditionally oil extraction is done by cold pressing [11], however, some factors make this technique disadvantageous, such as the residual lipid content in the pressing cake, which decreases the yield of the unit operation. Cake probably retains nutrients and bioactive compounds present in almonds [12]. Therefore, the solvent extraction method becomes an alternative to obtaining higher yields and minimize losses in the process [13].

The literature presents some extraction procedures of baru oil by solvents, with petroleum ether [10], [14] hexane [15] and ethanol [16]. Hexane is the most widely used solvent because it has high stability, a narrow boiling range, and it is immiscible with water, resulting in a low residual content in the cake. However, its flammability, higher toxicity, cost, and polluting potential justify the study of alternatives to the hexane use, such as ethanol, isopropanol, propanol, and butanol [16]. Isopropanol is less toxic and flammable than hexane and is efficient in the extraction of soybean oil [17], [18] cotton [19], and rice bran [20]. Ethanol is obtained from renewable sources, standing as a potential alternative for the use of petroleum derivatives in oilseed processing. The operational risks of using ethanol are lower due to its small flammability and toxicity. Besides, ethanol may also be used as a co-solvent in other processes, such as in supercritical $\mathrm{CO}_{2}$ extraction $\left(\mathrm{scCO}_{2}\right)$ [7].

This study aimed to optimize the solvent extraction of baru almond oil, investigating the use of alternative solvents to the hexane, e.g., ethanol and isopropanol. The influence of the type of the studied solvents on the oil extraction was evaluated regarding the parameters solid:solvent ratio (s:s ratio), temperature, and time in the extraction yield. The optimization aimed at to identify the levels of the variables that resulted in the best extraction yields and the lowest losses. A kinetic study was accomplished to determine the mass transfer parameters from the adjustment of kinetic models.

\section{MATERIALS AND METHODS}

Toasted and vacuum-packed baru almonds (Dipteryx alata Vog.) were purchased at the Central Market of Belo Horizonte town, Minas Gerais province, Brazil. The solvents used were hexane (98.5\%, Dinâmica, Brazil), isopropanol (99.5 \%, Dinâmica, Brazil) and ethanol (99.5 \%, Êxodo Científica, Brazil).

\subsection{ALMONDS PREPARATION}

The baru almonds were ground in a cutting mill, sieved and categorized according to its grain size, using sieves with sizes between 5 and 24 mesh. The granulometry of the cakes with higher retention in the sieves ( 9 and 12 mesh) was set as a process parameter, removing the influence of this factor on the extraction yield. Then, the material was sealed in glass jars, to avoid absorbing moisture.

\subsection{EXTRACTION IN A STIRRED BATCH REACTOR - $2^{3}$ CENTRAL COMPOSITE ROTATIONAL DESIGN}

The leaching operation was performed to remove and recover the oil from the solid mass of the grounded baru almonds through the solvent extraction. Then, the grounded almonds and solvents were added in $15 \mathrm{~mL}$ reactors in the pre-established quantities, following the experimental design presented in Table 1. The reactors were hermetically sealed and placed on heater plates with magnetic stirring. The extracted product was transferred to 15 $\mathrm{mL}$ tubes, and the reactors were washed with $3 \mathrm{~mL}$ of the respective solvents to eliminate oily residues on the reactor walls. Subsequently, the $15 \mathrm{~mL}$ tubes were centrifuged at $2260 \mathrm{~g}$ for $5 \mathrm{~min}$. The supernatant was transferred to test tubes and taken to a drying oven at $95{ }^{\circ} \mathrm{C}$ to evaporate the solvent to constant mass. The oil mass was determined by weighing after solvent evaporation.

The tests were performed according to central composite rotational design, 23 full factorial, 6 axial points - (also called star points) $-( \pm \alpha)$ and five repetitions at the center point, totaling 19 assays for each solvent. The three 
independent variables under study were: time, temperature, and solid:solvent ratio. These variable's ranges were determined in preliminary studies based on the characteristics of the studied solvents, as shown in Table 1.

Table 1: Variables and decoded levels of central composite rotational design for solvents hexane (H), ethanol (E), and isopropanol (I)

\begin{tabular}{|c|c|c|c|c|c|c|}
\hline \multirow{2}{*}{ Solvent } & Variables & \multicolumn{5}{|c|}{ Levels } \\
\cline { 3 - 7 } & & $-\alpha$ & -1 & 0 & 1 & $+\alpha$ \\
\hline \multirow{3}{*}{$\mathrm{H}$} & Time $(\mathrm{min})$ & 23 & 42 & 69 & 96 & 115 \\
\cline { 2 - 7 } & Temp. $\left({ }^{\circ} \mathrm{C}\right)$ & 30 & 45 & 65 & 85 & 100 \\
\cline { 2 - 7 } & Ratio s:s $(\mathrm{m} / \mathrm{v})$ & 0.05 & 0.075 & 0.1 & 0.15 & 0.2 \\
\hline \multirow{3}{*}{ E, I, and mixture of E:I (1:1) } & Time (min) & 130 & 150 & 180 & 210 & 230 \\
\cline { 2 - 7 } & Temp. $\left({ }^{\circ} \mathrm{C}\right)$ & 40 & 55 & 75 & 95 & 110 \\
\cline { 2 - 7 } & Ratio s:s (m/v) & 0.05 & 0.075 & 0.1 & 0.15 & 0.2 \\
\hline
\end{tabular}

The dependent variable (response) was oil extraction yield, calculated by Equation 1.

$$
R(\%)={ }^{M_{0}} /_{M_{a}} \cdot 100
$$

Whereby, Mo = Mass of extracted oil (g) and Ma = Mass of baru almond (g).

The effects of the studied variables taking into consideration the oil extraction were utilized for the analysis of the experiments. The test of significance of the regression model was performed by using the analysis of variance procedure (ANOVA), together with the lack of adjustment through F-statistic. The model coefficients were verified by using the t-test $(\mathrm{p}<0.05)$. The model effectiveness was also observed by checking the coefficient of determination $\left(\mathrm{R}^{2}\right)$.

\subsection{KINETIC ASSAY IN A BATCH REACTOR}

The tests to evaluate the mass transfer behavior for each solvent were performed under optimized conditions for the cases in which the time had a significant influence on yield. The tests were carried out similarly to the assays of experimental design. The time ranges were: $1,2,5,10,15,20,30,60,90$, and 120 minutes for hexane solvent and $5,10,15,20,25,30,60,120,180$, and 240 minutes for the other solvents. Equations 2 and 3 describe the kinetic models that were adjusted to the experimental data of the kinetic curve (R\% x time).

$$
\begin{aligned}
& R=R_{e} \cdot\left(1-e^{-k \cdot t}\right) \\
& \frac{t}{R}=\frac{1}{k \cdot R_{e}^{2}}+\frac{1}{R_{e}} \cdot t
\end{aligned}
$$

Where, $\mathrm{R}=$ extraction yield $(\%), \mathrm{Re}=$ maximum extraction yield $(\%), \mathrm{k}=$ mass transfer coefficient $\left(1 \mathrm{~min}^{-1}\right)$, and $\mathrm{t}=$ time $(\mathrm{min})$.

\section{RESULTS AND DISCUSSIONS}

\subsection{EXTRACTION OPTIMIZATION}

Table 2 shows the yields at each point of the experimental design for the analyzed solvents.

Table 2: Experimental design responses for solvents

\begin{tabular}{|c|c|c|c|c|c|c|c|}
\hline ID & \multicolumn{3}{|c|}{ Coded } & \multicolumn{5}{c|}{ Yield (\%) } \\
\cline { 2 - 7 } & Time (min) & Temp. $\left({ }^{\circ} \mathrm{C}\right)$ & Ratio s:s (m/v) & $\begin{array}{c}\text { Hexane } \\
(\mathrm{H})\end{array}$ & $\begin{array}{c}\text { Iso } \\
\text { Propanol (I) }\end{array}$ & Ethanol (E) & $\begin{array}{c}\text { Mixture } \\
(\mathrm{I}+\mathrm{E})\end{array}$ \\
\hline
\end{tabular}




\begin{tabular}{|c|c|c|c|c|c|c|c|}
\hline 1 & -1 & -1 & -1 & 32.39 & 37.51 & 18.06 & 37.96 \\
\hline 2 & 1 & -1 & -1 & 33.78 & 36.14 & 18.43 & 37.77 \\
\hline 3 & -1 & 1 & -1 & 31.90 & 31.41 & 17.43 & 31.92 \\
\hline 4 & 1 & 1 & -1 & 34.26 & 32.93 & 18.00 & 33.34 \\
\hline 5 & -1 & -1 & 1 & 34.25 & 35.90 & 28.35 & 40.26 \\
\hline 6 & 1 & -1 & 1 & 36.59 & 37.21 & 29.12 & 38.61 \\
\hline 7 & -1 & 1 & 1 & 31.21 & 35.32 & 21.74 & 36.91 \\
\hline 8 & 1 & 1 & 1 & 32.05 & 36.33 & 19.97 & 29.68 \\
\hline 9 & -1.682 & 0 & 0 & 35.91 & 36.23 & 20.96 & 35.46 \\
\hline 10 & 1.682 & 0 & 0 & 35.74 & 35.27 & 28.95 & 38.32 \\
\hline 11 & 0 & -1.682 & 0 & 35.47 & 39.66 & 24.04 & 41.13 \\
\hline 12 & 0 & 1.682 & 0 & 30.16 & 31.16 & 17.96 & 25.32 \\
\hline 13 & 0 & 0 & -1.682 & 31.61 & 36.87 & 22.10 & 36.47 \\
\hline 14 & 0 & 0 & 1.682 & 33.11 & 35.94 & 23.55 & 37.82 \\
\hline 15 & 0 & 0 & 0 & 32.67 & 34.97 & 23.25 & 36.79 \\
\hline 16 & 0 & 0 & 0 & 32.65 & 34.27 & 23.11 & 37.39 \\
\hline 17 & 0 & 0 & 0 & 33.39 & 35.06 & 22.96 & 36.89 \\
\hline 18 & 0 & 0 & 0 & 33.15 & 34.27 & 23.82 & 36.99 \\
\hline 19 & 0 & 0 & 0 & 32.67 & 34.80 & 23.25 & 37.32 \\
\hline
\end{tabular}

The effects of each studied variable and the coefficients of the proposed model were evaluated for the data analysis of the central composite rotational design (CCRD). The Pareto graphs were used to verify the significance analysis of the effects based on both the statistical differences of the effects and the respective standard errors utilizing the t-test, at a significance level of $5 \%$. The adjusted model was evaluated by the lack of adjustment, through the Analysis of Variance (ANOVA), identity analysis, and residue distribution analysis. The results were represented in response surfaces and contour plots. The identity analysis was performed using the linear regression of the graph generated by the measured and predicted values of the model.

\subsubsection{HEXANE}

Figure 1. represent the response surface of the effects of the process parameters on the extraction of the baru almond oil using the solvent hexane. Appendices A1 represent Pareto graph, and Appendices B1 the contour plot for the same case.

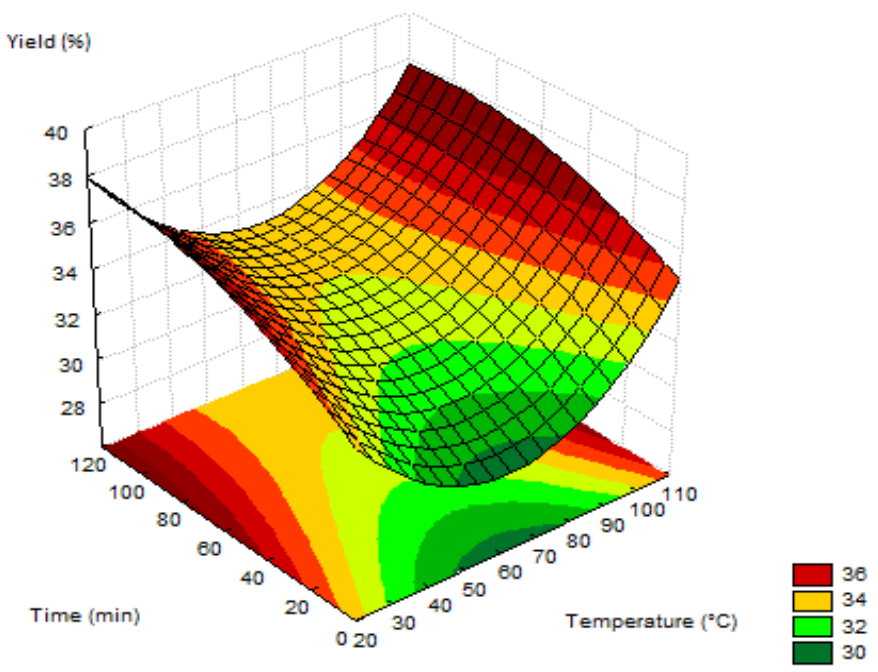

Figure 1: Response surface graph of the yield of Baru almond oil extraction using hexane as solvent as a function of time and temperature (ratio: 1/10). 
In Fig. 1 it is possible to observe the quadratic effect of the temperature and the small significance effect of the time. The analysis of Figure 1S, allows us to infer that the factors temperature (1), solid:solvent ratio (2), time (3), and the interaction of temperature and solid:solvent ratio affect the extraction yield. The effect of solid:solvent ratio is linear (L) and the most significant in the oil extraction. The yields under all conditions applied were satisfactory for the solvent hexane, regarding the reference values $(39.41 \% \pm 0.31 \%$ and $37.19 \% \pm 0.49 \%)$ and the maximum extraction yield was $36.59 \%$, obtained under the conditions of $0.75: 10$ of solid:solvent ratio, $85^{\circ} \mathrm{C}$ of temperature, and 96 min of extraction time.

The positive effect on yield as a function of the decrease of the solid:solvent ratio and the increase in temperature is due to the increase in the oil solubility in the solvent, at higher temperatures, which decreases the viscosity in the solution. These results corroborate those reported for the extraction of cottonseed oil, for which the temperature increase, intermediate times, and low solid:solvent ratios provided the best extraction yields [21].

\subsubsection{ISOPROPANOL}

Figure 2 represents the response surface of the effects of the process parameters on baru almond oil extraction using the solvent isopropanol. Appendices A2 represent Pareto graph, and Appendices B2 the contour plot for the same case.

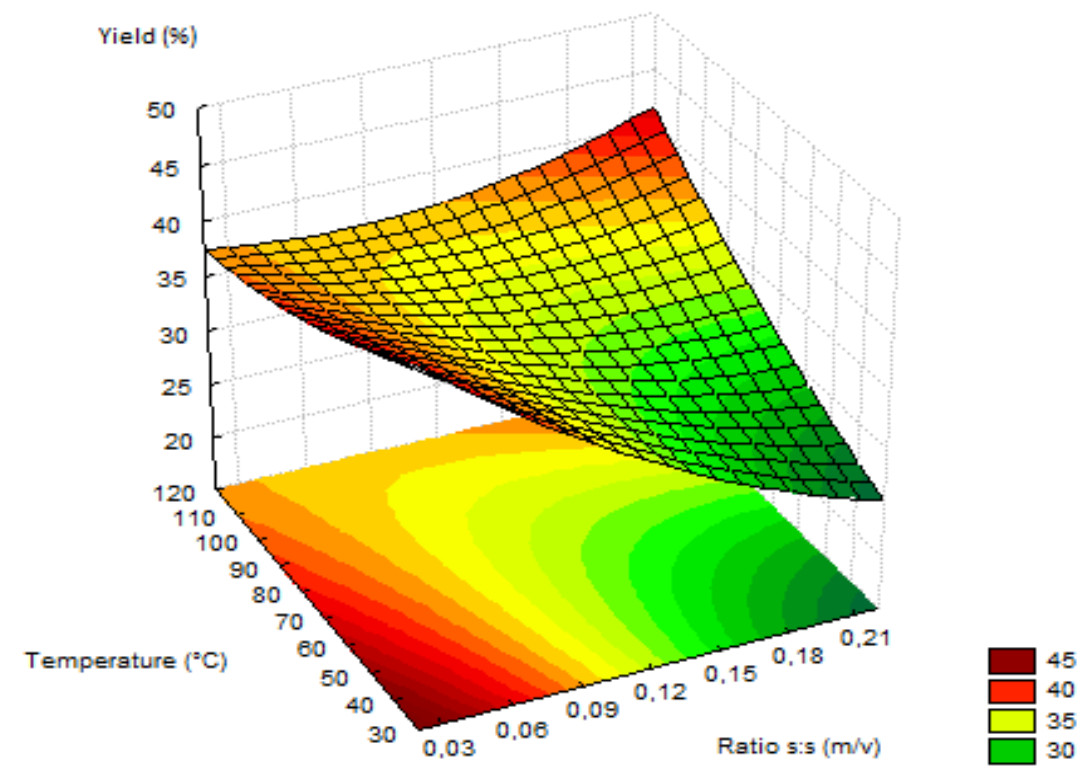

Figure 2: Response surface graph of the yield of baru almond oil extraction using isopropanol as solvent as a function of s:s ratio and temperature (time: $180 \mathrm{~min}$ ).

In Fig. 2, it is observed a variation in yield with the decrease of the solid:solvent ratio in the approximate temperature range between 40 to $75^{\circ} \mathrm{C}$. For temperatures above $75^{\circ} \mathrm{C}$, this variation becomes less significant. Fig. A2 reveals the large influence of the linear effect of the solid:solvent ratio on the extraction yield of baru oil using isopropanol. For this solvent, the interaction effect between the solid:solvent ratio is considerable.

\subsubsection{ETHANOL}

Figure 3 represent, respectively, the response surface of the effects of the process parameters on the extraction of the baru almond oil using the ethanol as solvent. Appendices A3 represent Pareto graph, and Appendices B3 the contour plot for the same case. 


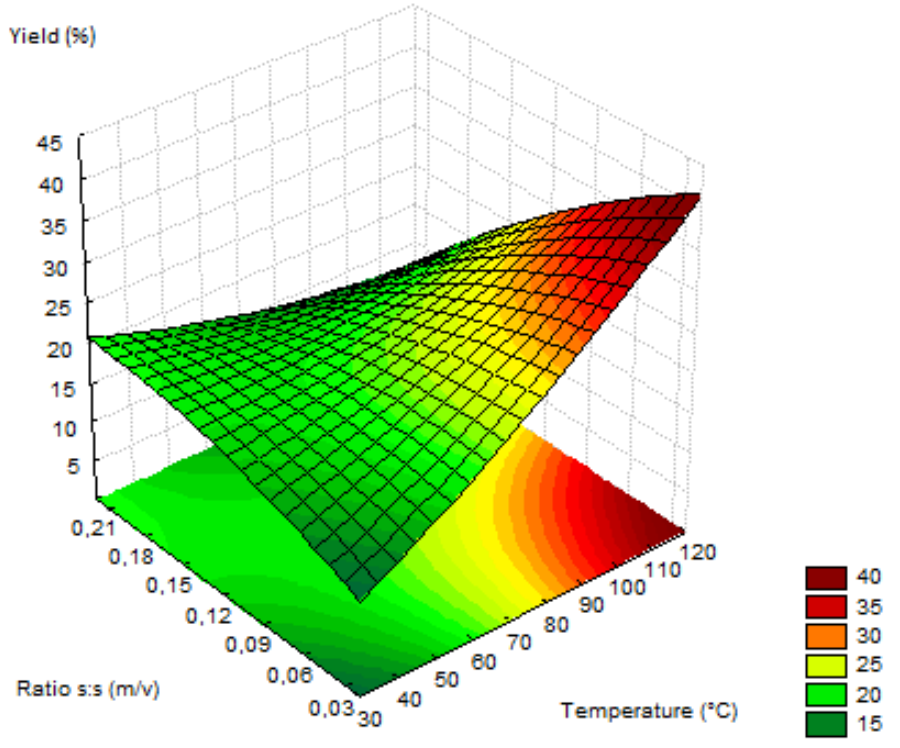

Figure 3: Response surface graph of the yield of Baru almond oil extraction using ethanol as solvent as a function of s:s ratio and temperature variation (time: $180 \mathrm{~min}$ ).

In the extraction of baru oil with ethanol, the temperature was the variable that showed the greatest influence. The oil extraction was significant only at temperatures above $80^{\circ} \mathrm{C}$. Only at high temperatures, the effect of the solid:solvent ratio became significant and negative. In other words, at high temperatures, the lower the ratio, the higher the extraction yield. Sawada et al. [17] analyzed the extraction of soybean meal using ethanol, and the elevation of temperature from $40{ }^{\circ} \mathrm{C}$ to $60^{\circ} \mathrm{C}$ and $90^{\circ} \mathrm{C}$ favored the transfer of lipid compounds.

\subsubsection{MIXTURE OF SOLVENTS ETHANOL: ISOPROPANOL (1:1)}

Figure 4 represent the response surface of the effects of the process parameters on baru almond oil extraction employing the mixture of ethanol:isopropanol (1:1) as the solvent. Pareto graph and the contour plot are in Appendice A4 and B4, respectively.

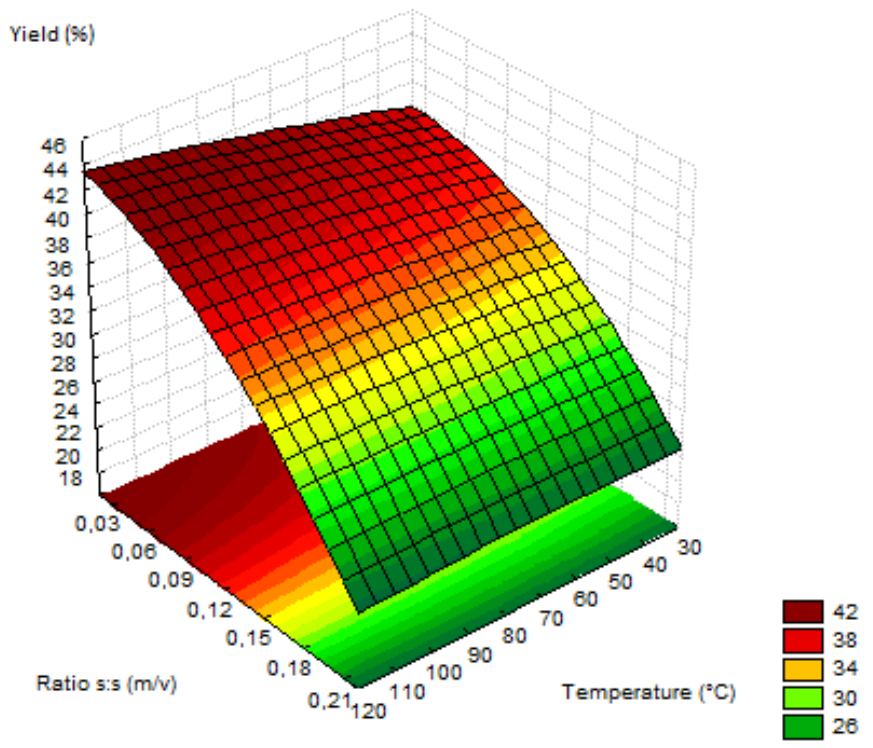

Figure 4: Response surface graph of the yield of Baru almond oil extraction using the isopropanol:ethanol mixture (1:1) as solvent as a function of s:s ratio and temperature variation (time: $180 \mathrm{~min}$ ). 
The figures cited above allows inferring that the negative effect of the solid:solvent ratio is the one that most affects the extraction yield when the solvent is the isopropanol:ethanol (1:1) mixture, followed by the negative effect of the interaction between temperature and linear time. As already discussed in the former Pareto diagrams, the lower the solid:solvent ratio, the higher the extraction yield, as evidenced by the higher extraction yield (41.13 \%) for the lower solid:solvent ratio (0.5/10).

Abdelmoez et al. [21] considered this behavior to be an important parameter in oil extraction due to its effect on minimizing diffusion limitations during the extraction process. However, unlike the other solvents, the temperature revealed little influence on the oil extraction yield.

\subsection{YIELD ANALYSIS}

The analysis of the set of all solvents allows making some conclusions. Based on the experimental results of the hexane, the yields were satisfactory, approximate $35 \%$, throughout the studied temperature range, probably because the hexane solubilizes the oil easily. The boiling temperature of hexane is relatively low ( $\left.68{ }^{\circ} \mathrm{C}\right)$ that enable the occurrence of the extraction in the early contact stages.

On the other hand, lower yields happened if ethanol was used as the solvent, even in the highest studied temperatures, of $95^{\circ} \mathrm{C}$ and $110{ }^{\circ} \mathrm{C}$, with yields of $29.12 \%$ and $28.95 \%$, respectively. These values are lower than the ones found for the other solvents.

Nevertheless, the increase in temperature considerably increased the extraction using ethanol. The isopropanol presented higher extraction percentages in all the studied temperatures as compared with both ethanol and hexane. Thus, isopropanol has great relevance, provided that even at lower temperature, the extraction yields are satisfactory. Thus, the solvent ability to solubilize the oil is high. Besides, the carbonic chain of the isopropanol is bigger than the ethanol one, which makes it more suitable for extraction of nonpolar functional groups.

In summary, the maximum yields were obtained under the conditions of: (i) for hexane, yield of $36.59 \%$, at 85ํㅡ, solid:solvent ratio of 0.75:10, 96 minutes of extraction; (ii) for ethanol: yield of $29.12 \%$, at $95{ }^{\circ} \mathrm{C}$, solid:solvent ratio of $0.75: 10,210$ minutes of extraction; (iii) for isopropanol, yield of $39.66 \%, 75^{\circ} \mathrm{C}$, solid:solvent ratio $0.5: 10$, 180 min. of extraction; (iv) for mixture of isopropanol:ethanol (1:1,) yield of $41.13 \%$ under the same conditions observed when the isopropanol solvent was employed.

\subsection{MODELS ANALYSIS}

The Pareto Graphs, ANOVA, identity analysis, and distribution graphs of model's residues were performed to study the extraction yield models as a function of temperature, time, and solid:solvent ratio. The identity analysis consists of the evaluation of the determination coefficient $\left(\mathrm{R}^{2}\right)$ of measured values versus the predicted values by the model. Table 3 represents the ANOVA of the models for each solvent.

Table 3: Regression coefficients of the quadratic equations for the process parameters

\begin{tabular}{|c|c|c|c|c|c|c|c|c|c|}
\hline Factors & & Hexane & $p$ & Ethanol & $p$ & Isopropanol & $p$ & Mixture & $p$ \\
\hline & $\beta_{0}$ & 32.561 & - & 22.472 & - & 34.164 & - & 36.199 & - \\
\hline Temp. (L) & $\beta_{1}$ & -0.020 & 0.9142 & 2.689 & 0.0001 & 0.518 & 0.0911 & 0.634 & 0.0943 \\
\hline Temp. (Q) & $\beta_{1}{ }^{2}$ & 0.914 & 0.0005 & 0.327 & 0.4406 & 0.295 & 0.2869 & -0.051 & 0.8785 \\
\hline Ratio s:s (L) & $\beta_{2}$ & -1.165 & 0.0001 & -1.807 & 0.0022 & -1.828 & 0.0001 & -3.195 & 0.0001 \\
\hline Ratio s:s (Q) & $\beta_{2}{ }^{2}$ & 0.109 & 0.4618 & -0.285 & 0.4178 & 0.359 & 0.1311 & -0.506 & 0.0914 \\
\hline time (L) & $\beta_{3}$ & 0.690 & 0.0042 & 0.127 & 0.7744 & 0.120 & 0.6766 & -0.484 & 0.1932 \\
\hline time (Q) & $\beta_{3}^{2}$ & -0.234 & 0.2298 & -0.428 & 0.3502 & 0.551 & 0.0799 & 0.040 & 0.9103 \\
\hline $\mathrm{T} \times \mathrm{r}$ & $\beta_{1} \beta_{2}$ & -0.865 & 0.0043 & -1.598 & 0.0163 & 1.091 & 0.0123 & -0.251 & 0.5755 \\
\hline $\mathrm{T} \times$ time & $\beta_{1} \beta_{3}$ & -0.070 & 0.7723 & -0.242 & 0.6727 & 0.271 & 0.4676 & -1.264 & 0.0190 \\
\hline $\mathrm{r} \times$ time & $\mathrm{B}_{2} \beta_{3}$ & -0.007 & 0.9760 & -0.337 & 0.5498 & 0.387 & 0.2974 & -0.653 & 0.1658 \\
\hline & $\mathrm{R}^{2}$ & 0.925 & - & 0.907 & - & 0.875 & - & 0.944 & - \\
\hline
\end{tabular}

Figure 5 expresses the identity graphs for the extraction yield models as a function of temperature, time, and solid:solvent ratio for the solvents: hexane (a), isopropanol (b), ethanol (c), and a mixture of ethanol:isopropanol 
(1:1) (d). The model that presented the best coefficient of determination $\left(\mathrm{R}^{2}\right)$ was the solvent mixture (0.944), followed by hexane (0.925), isopropanol (0.907), and ethanol (0.875). All models showed a random distribution of residues, as can be observed in Fig. 6.

a)

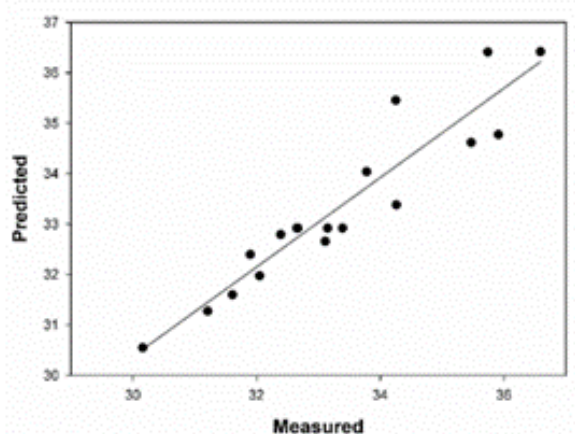

c)

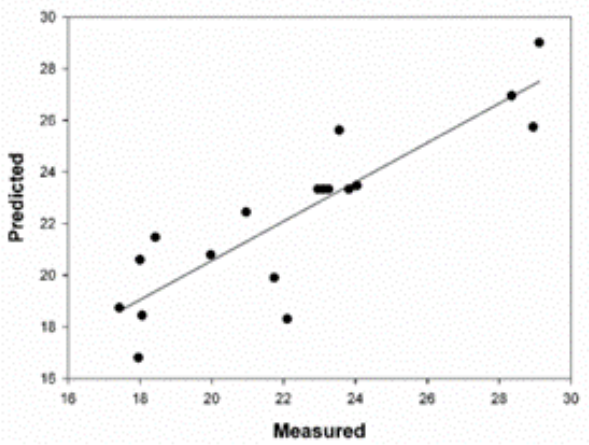

b)

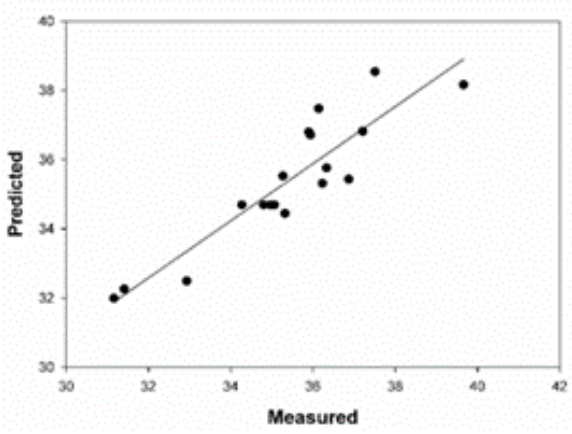

d)

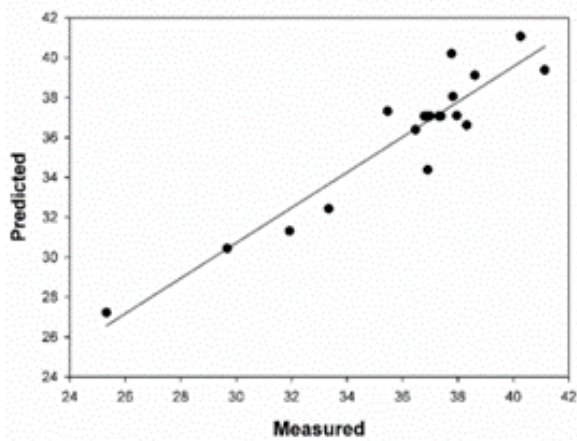

Figure 5: Identity analysis graphs of the models for the solvents hexane (a), isopropanol (b), ethanol (c) and mixture of ethanol:isopropanol (1:1) (d).

a)
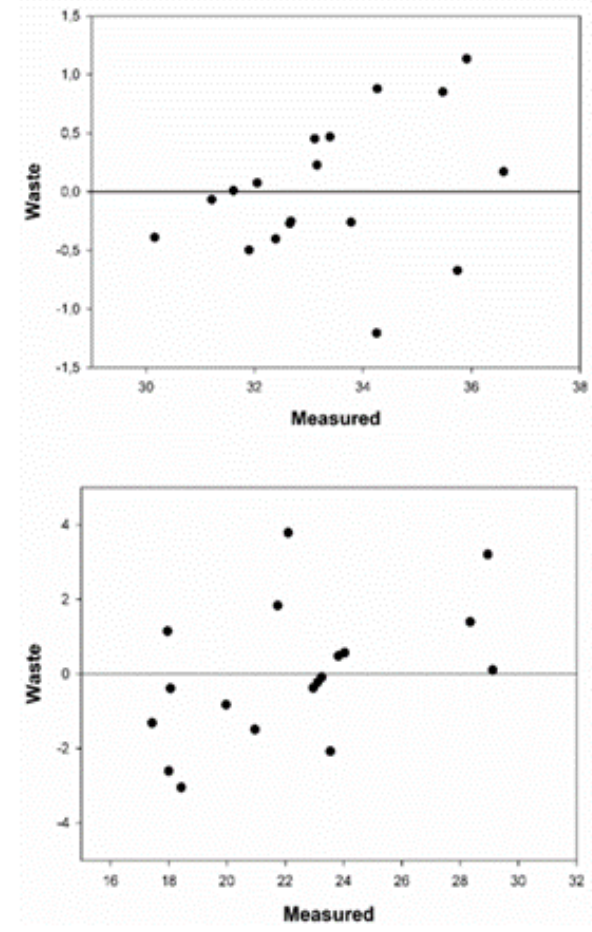

b)

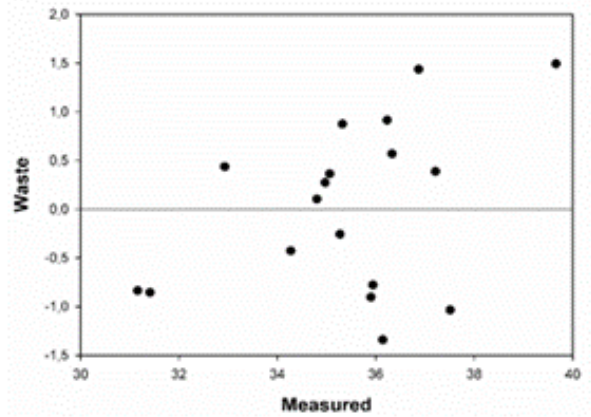

d)

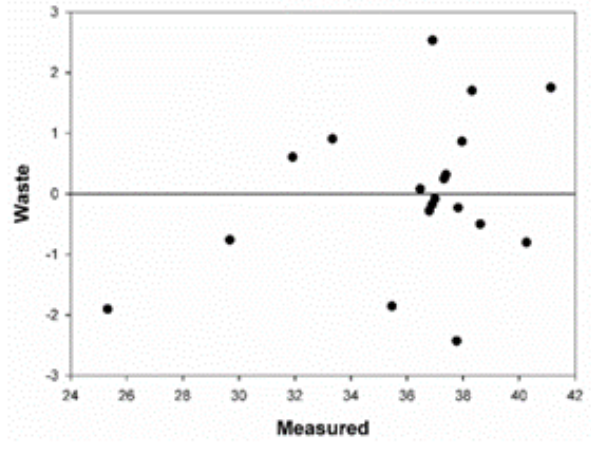

Figure 6: Distribution graphs of models' residues for the solvents: hexane (a), isopropanol (b), ethanol (c), and mixture of ethanol:isopropanol (1:1) (d) 


\subsection{EXTRACTION KINECTICS}

In the experiments that the variable time was a significant parameter in the extraction yield, namely, in the solvents hexane and isopropanol:ethanol (1:1), kinetic assays were performed in order to determine the mass transfer coefficients and the behavior of each extraction. For these trials, the experimental conditions applied were similar to those that showed the best extraction yields for each of the solvents. In the kinetic curves shown in Fig. 7, it is inferred that hexane extracts the baru oil faster when compared to the isopropanol:ethanol solvent mixture, for the same extraction yield (33\%).

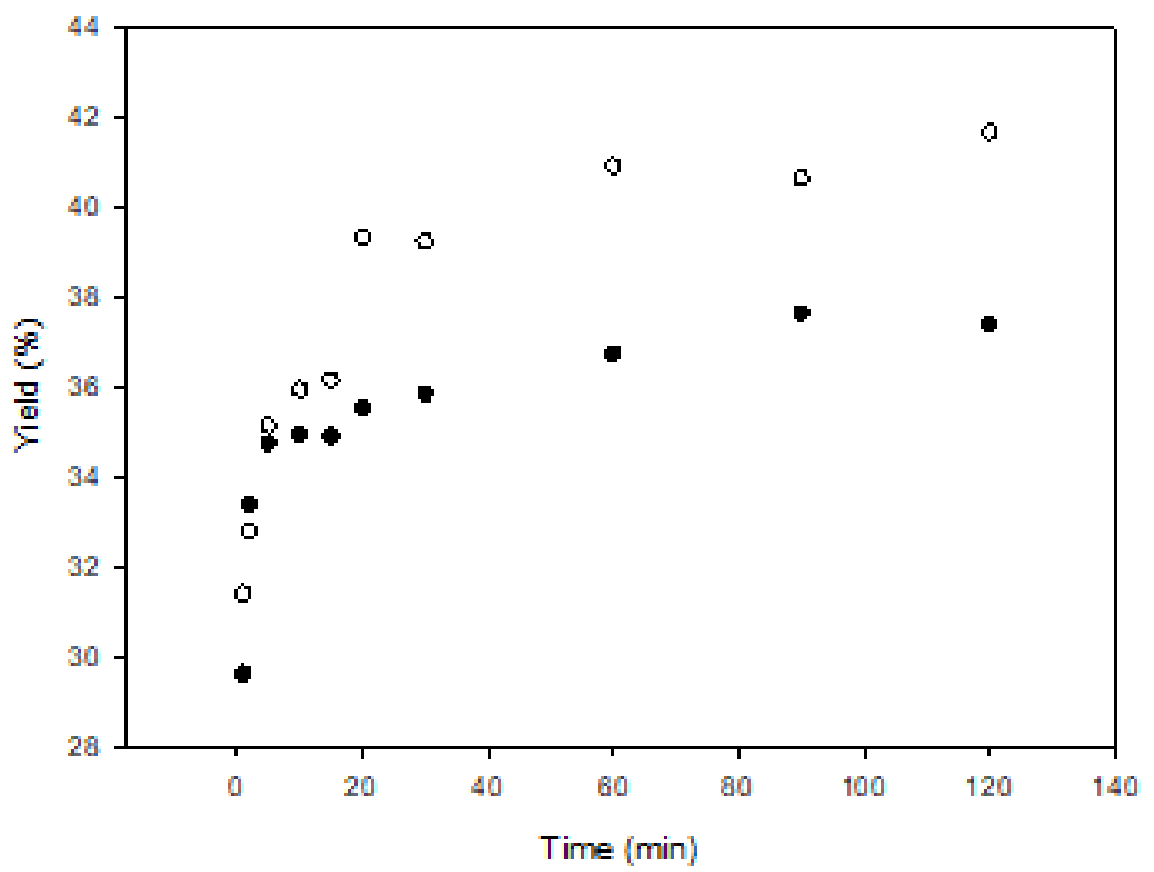

Figure 7: Kinetic curves of baru almond oil extraction using: (๑) hexane and (०) isopropanol: ethanol (1:1).

However, if the yields are analyzed in longer extraction times, the isopropanol:ethanol mixture shows better results, what can be justified by a possible drag of non-lipid compounds, but to verify this hypothesis, more detailed qualitative tests of the extracted oil should be done.

In the experiments performed, it is possible to note that most of the extraction occurs in the first moments, leading to the conclusion that the stage of washing the oil superficially set in the matrix is fast if compared to the diffusion stage of the internal oil of the seeds. As the experimental ratios for solid:liquid were low, after one hour of extraction, the extraction yield showed minimal variability, confirming the hypothesis that the largest amount of oil to be extracted is done in small time frames, so the solvent starts to saturate with oil, leading to a low extraction rate.

For hexane, the system achieve the equilibrium one hour after the beginning of the extraction, fact that cannot be applied for the mixture. However, it is worth mentioning that the mixture behaves similarly to hexane in the extraction process and, above all, its yields are more satisfactory (41.6\%).

The first order model presented lower correlation coefficients values than those obtained with the second order model. Therefore, baru oil extraction process is described by the last correlation. The adjustment to the second order model, Appendice $\mathrm{C}$, allows to state that in the conditions under study, the washing of the surface oil and the diffusion of the oil trapped inside the solid matrix are both involved in the extraction process.

The mass transfer coefficient is a parameter that depends on the extraction conditions, such as those studied in the optimization, thus justifying the $\mathrm{k}$ values obtained $\left(0.0338 \mathrm{~L} \mathrm{~min}^{-1}\right.$ for hexane and $0.0080 \mathrm{~L} \mathrm{~min}^{-1}$ for isopropanol:ethanol) being different. Regarding the initial extraction velocity $(\mathrm{h})$, the literature reports values around 0.011 and $2.9 \times 10^{-3}\left(\mathrm{~g} \mathrm{~mL}^{-1} \cdot \mathrm{min}^{-1}\right)$ [22,23], such parameter is related to concentration in the extraction micelle. Greater solids:solvent proportions result in lower oil concentrations in the micelle, reflecting a lower initial 
extraction velocity, what justifies the value found for isopropanol:ethanol being higher than for hexane, $125 \mathrm{~g} \mathrm{~mL}$ ${ }^{1}$. $\mathrm{min}^{-1}$ and $30 \mathrm{~g} \mathrm{~mL}^{-1} \cdot \mathrm{min}^{-1}$, respectively.

The solvent mixture isopropanol:ethanol (1:1) was able to extract more oil from the almond at the end of the process than the solvent hexane, $38 \%$ and $42 \%$ respectively. Therefore, isopropanol:ethanol (1:1) is shown as a potential alternative for the use of hexane as extractive solvent in oilseeds, in particular, baru oil.

\section{CONCLUSIONS}

According to the results obtained in this work it can be concluded that it is possible to use alternative solvents in the baru almond oil extraction process, and that these alternatives are potentially promising for hexane replacement.

In general, the extraction of baru almond oil using isopropanol, ethanol and hexane, presented satisfactory results. Isopropanol has been shown to be a solvent with great potential to replace hexane due to the very similar extraction behavior. The extraction process, for this latter solvent, was efficient even when low temperatures were applied, proving to be a viable process on an industrial scale. However, ethanol also showed good yield results. The efficient use of ethanol for oils extraction demonstrates that greater care must be taken with the choice of process conditions, point that can be further studied in a future work. The isopropanol:ethanol (1:1) mixture is considerably the best substitution for hexane since the ethanol and isopropanol combination, besides making the extraction process more efficient, makes it more economically viable due to its availability, low cost and lower toxicity of these solvents.

\section{APPENDICES}

\section{Appendice A - Pareto Diagrams}

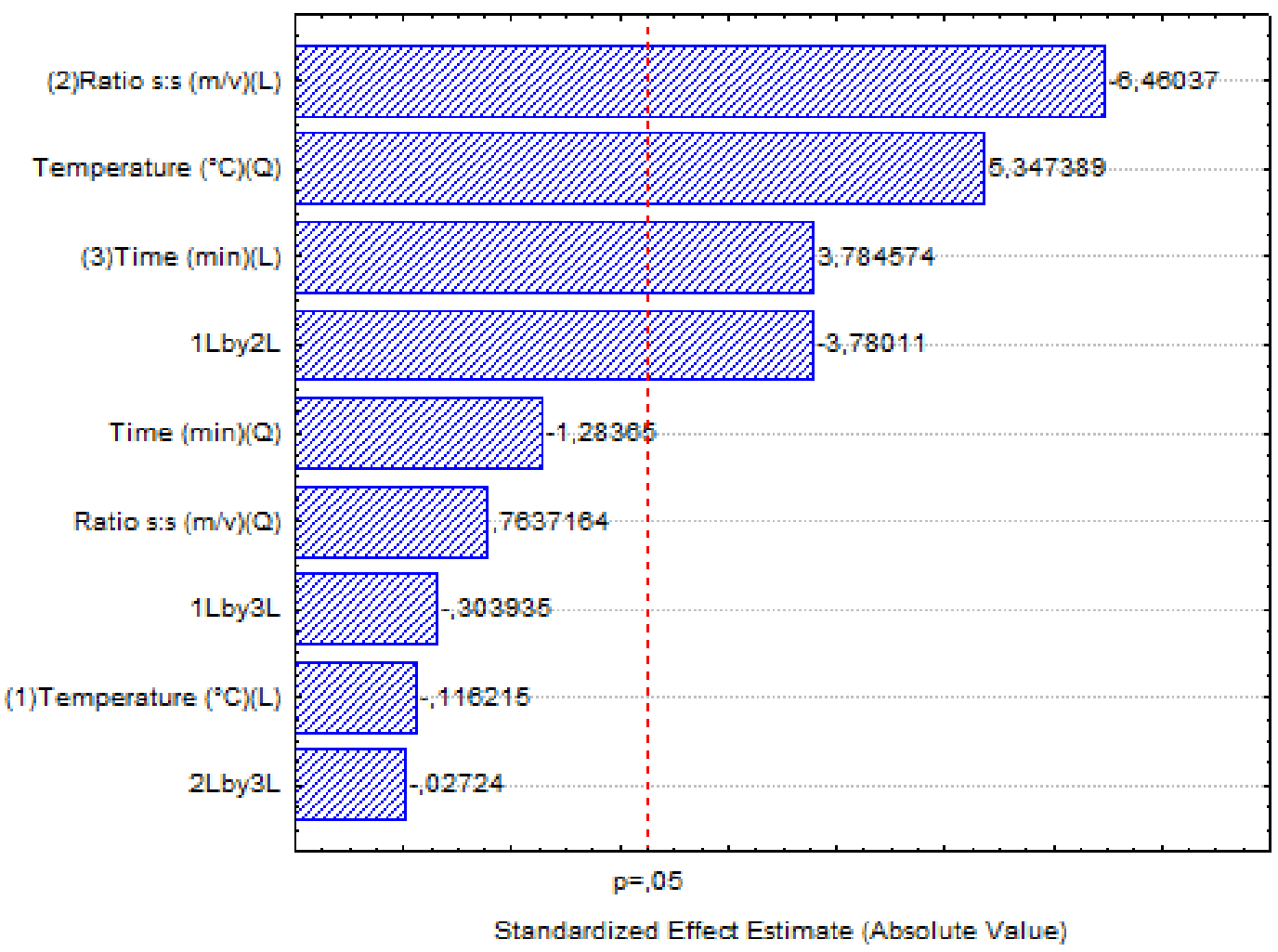

Appendice A1: Pareto diagram of the effects of the process parameters on Baru almond oil extraction using the solvent hexane. 
Ana Luísa S. Souza, Julia S. Miranda, Rita C. S. Sousa, Bruno B. Vieira, and Jane S. R. Coimbra

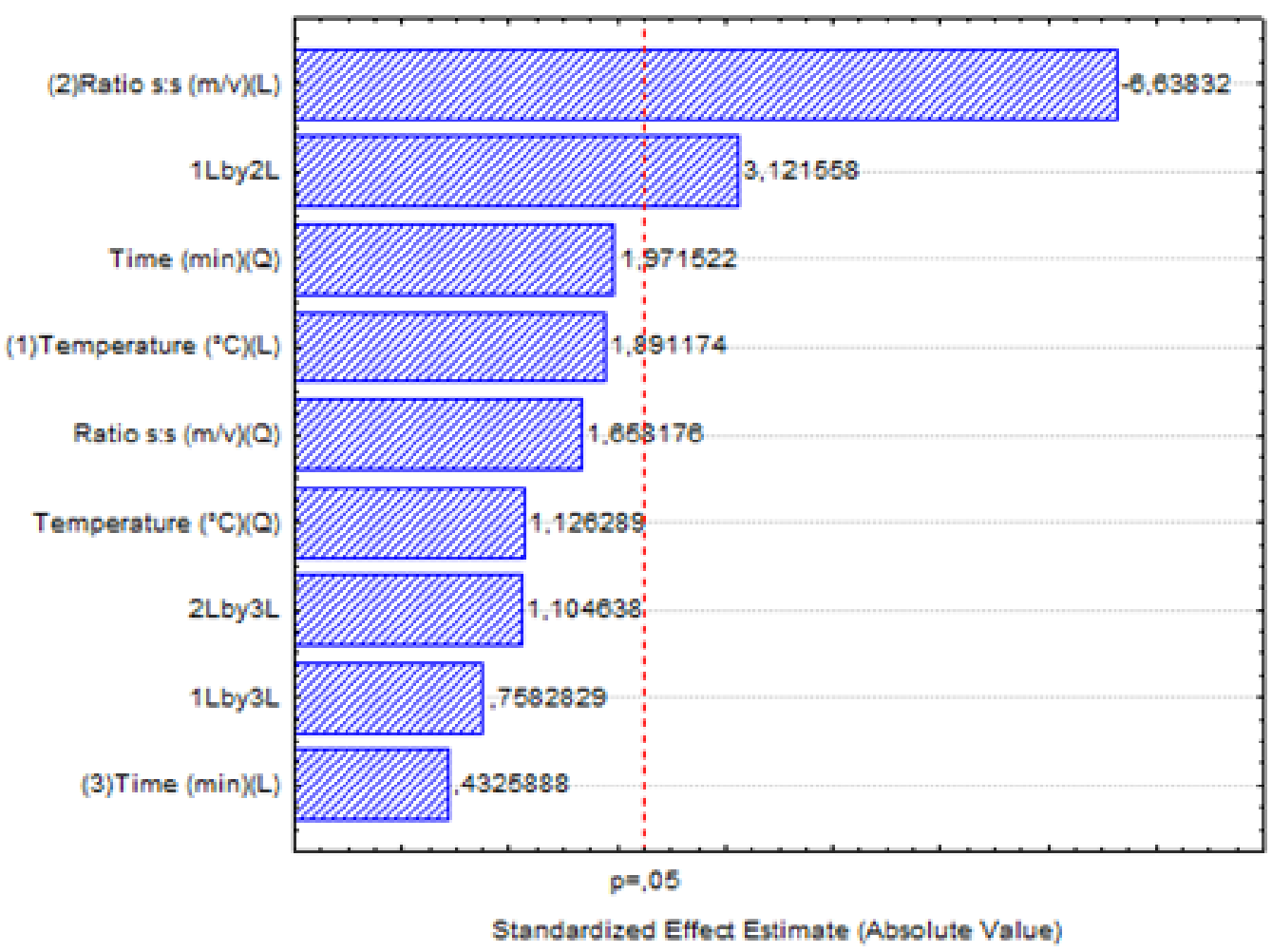

Appendice A2: Pareto diagram for the effects of the process parameters on baru almond oil extraction using the solvent isopropanol.

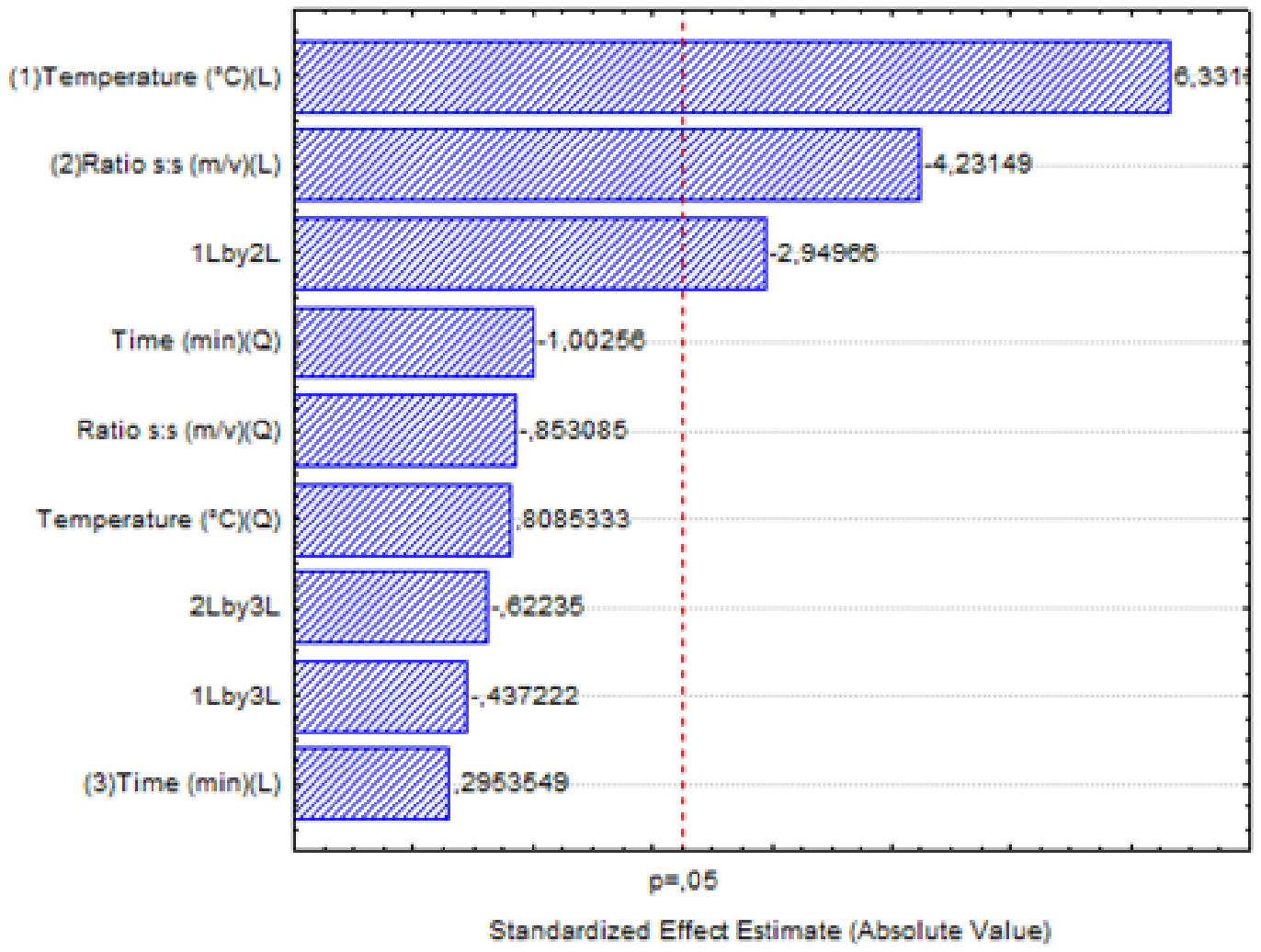

Appendice A3: Pareto diagram for the effects of process parameters on Baru almond oil extraction using the solvent ethanol. 
Extraction of Baru Almond Oil Using Alternative Solvents to Hexane: Ethanol and Isopropanol

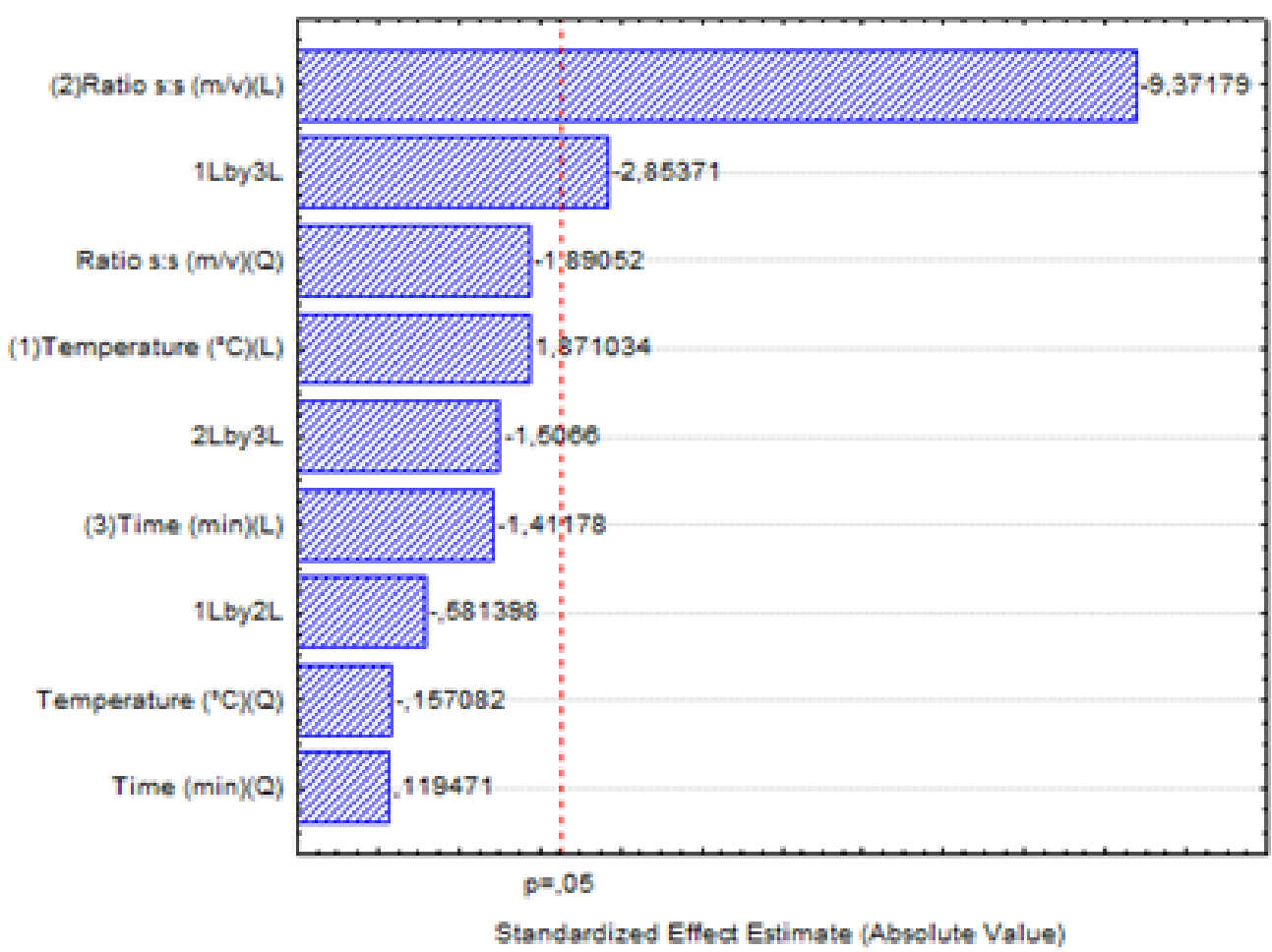

Appendice A4: Pareto diagram for the effects of process parameters on baru almond oil extraction using the mixture of solvents isopropanol:ethanol (1:1).

\section{APPENDICE B - Contour plots}

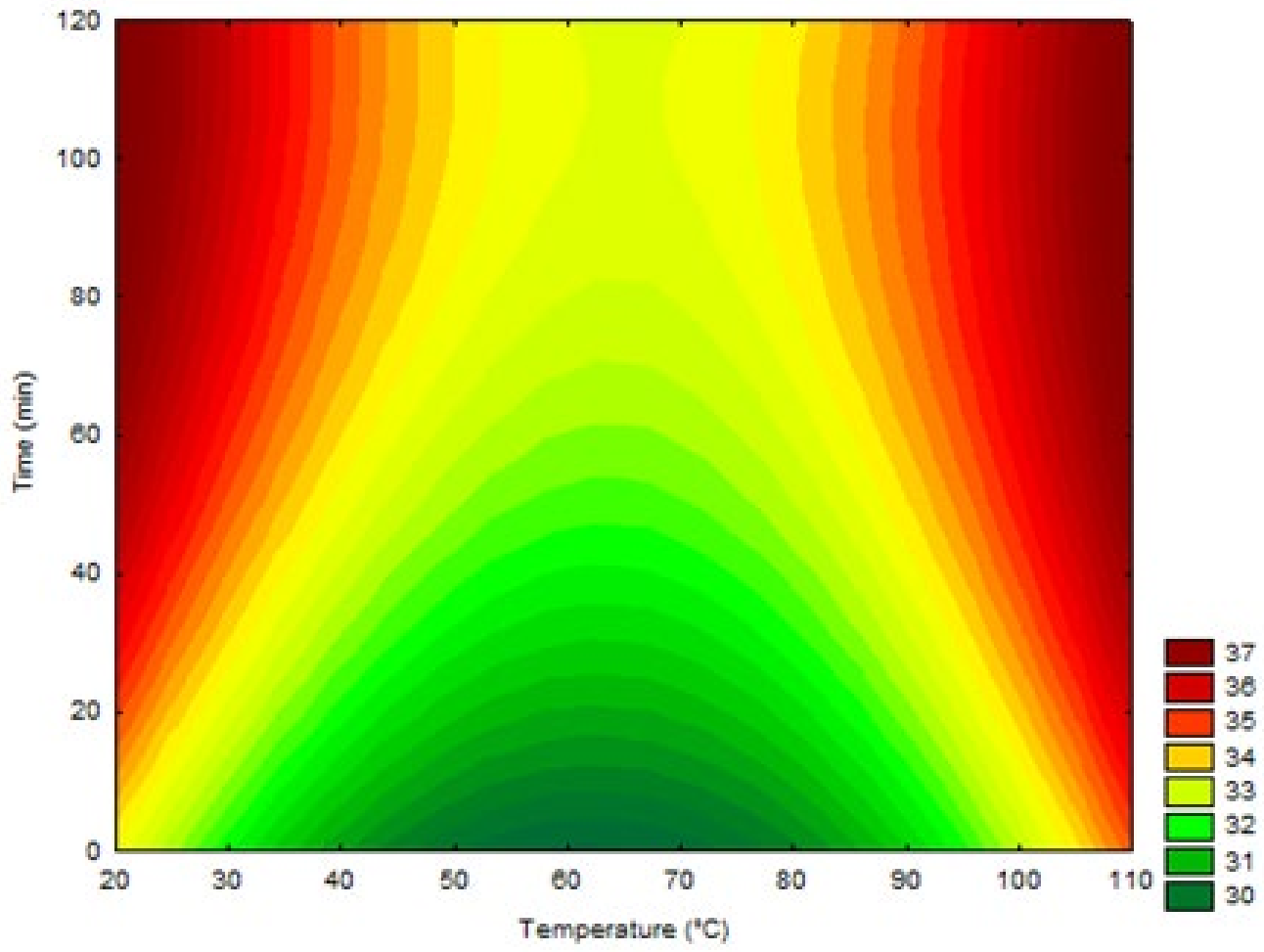

Appendice B1: Contour plot of baru almond oil extraction yield using hexane as solvent as a function of time and temperature (ratio: $1 / 10$ ). 
Ana Luísa S. Souza, Julia S. Miranda, Rita C. S. Sousa, Bruno B. Vieira, and Jane S. R. Coimbra

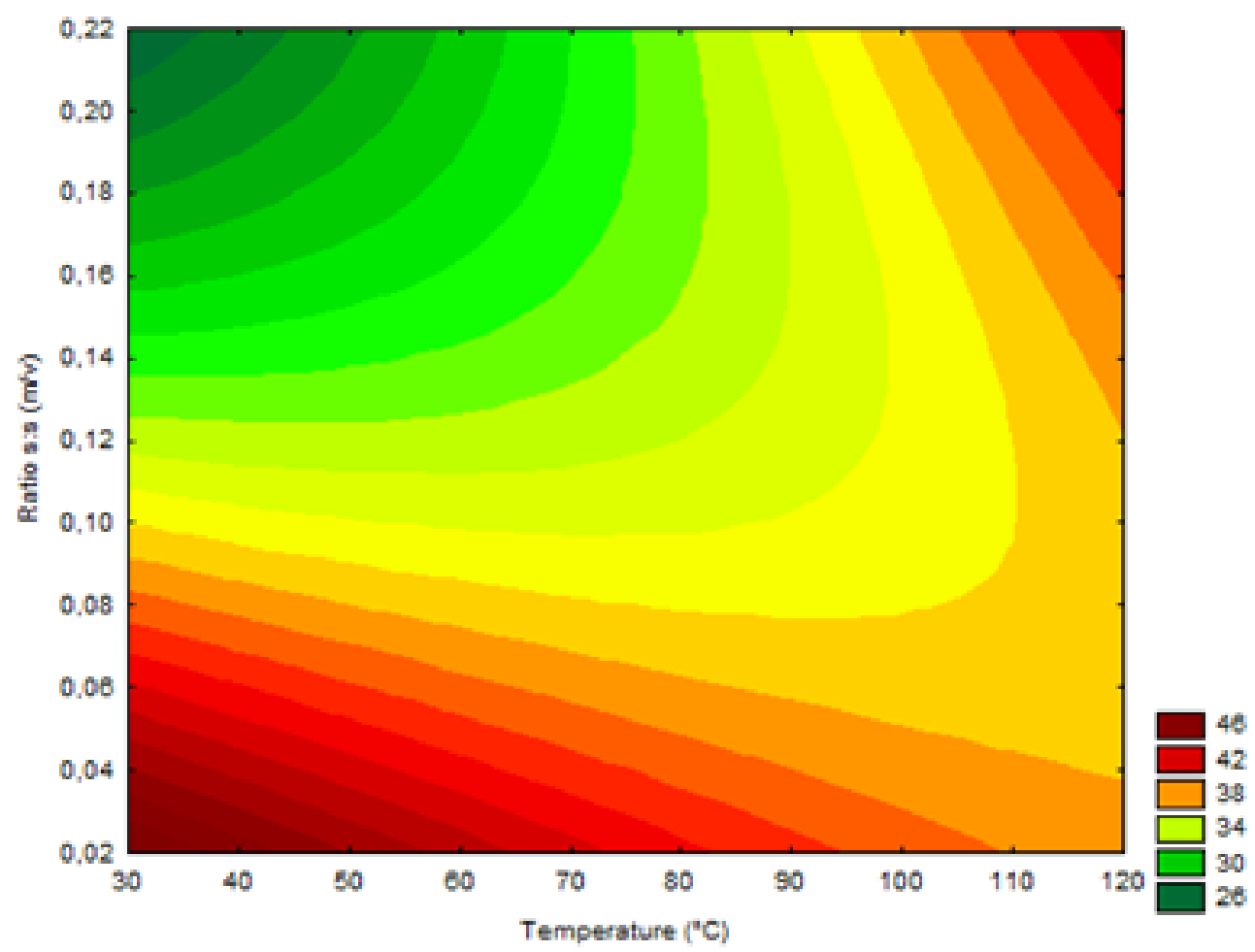

Appendice B2: Contour plot of baru almond oil extraction yield using isopropanol as a solvent as a function of s:s ratio and temperature (time: $180 \mathrm{~min}$ ).

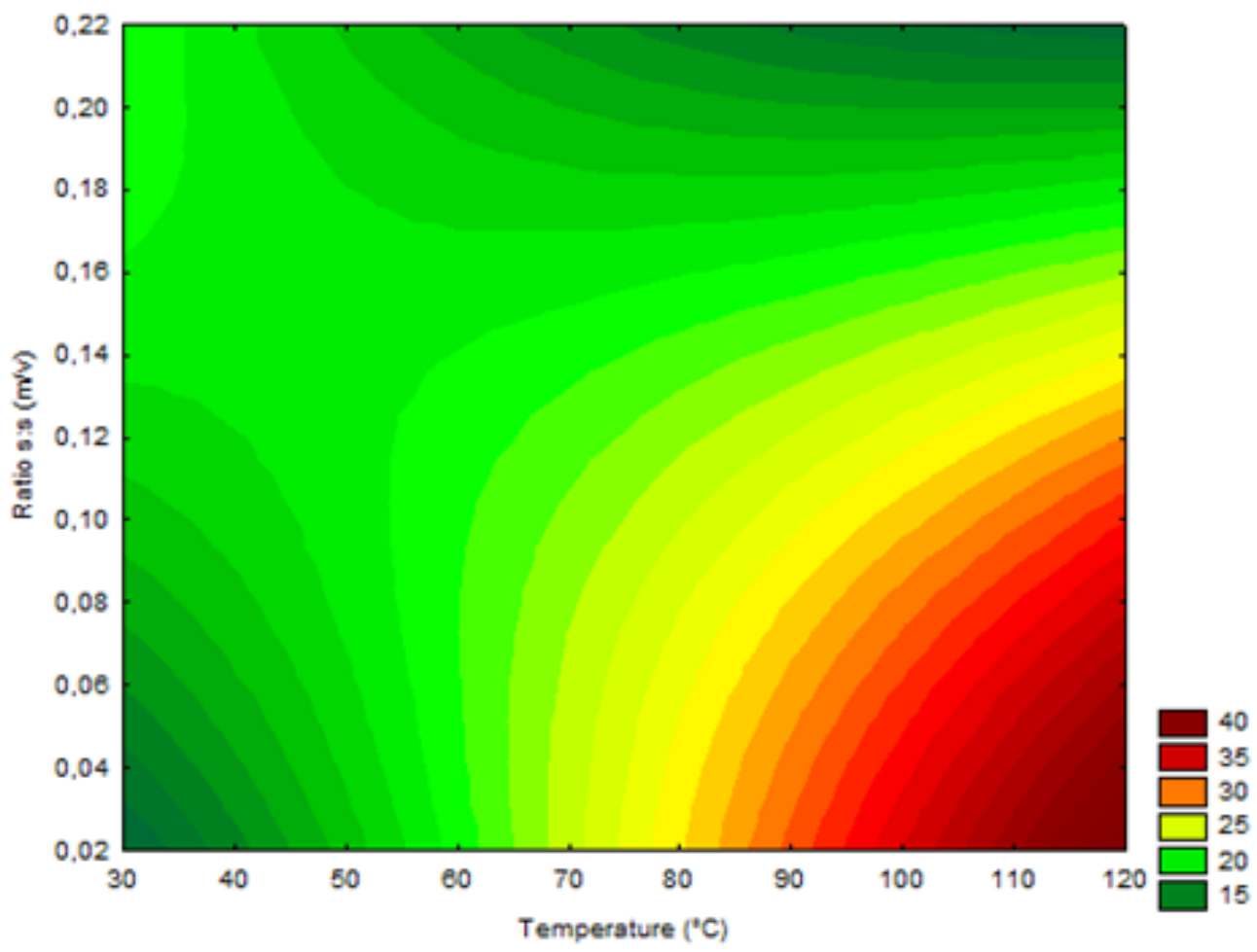

Appendice B3: Contour plot of baru almond oil extraction yield using ethanol as solvent as a function of s:s ratio and temperature (time: $180 \mathrm{~min}$ ). 


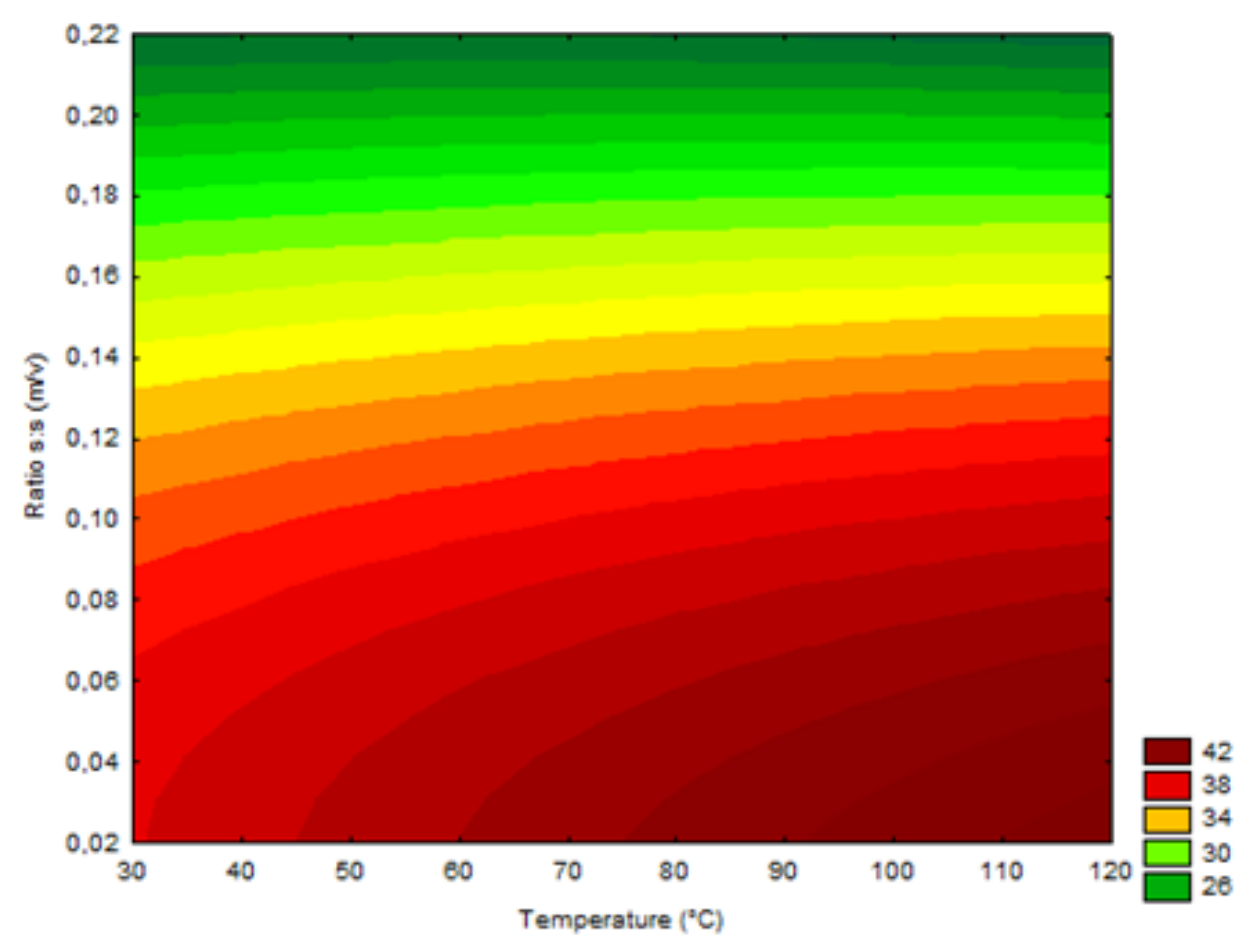

Appendice B4: Contour plot of baru almond oil extraction yield using the isopropanol:ethanol (1:1) mixture as solvent as a function of s:s ratio and temperature variation (time: $180 \mathrm{~min}$ ).

APPENDICE C - Kinetic curve adjustment to the second order model for baru almond oil extraction

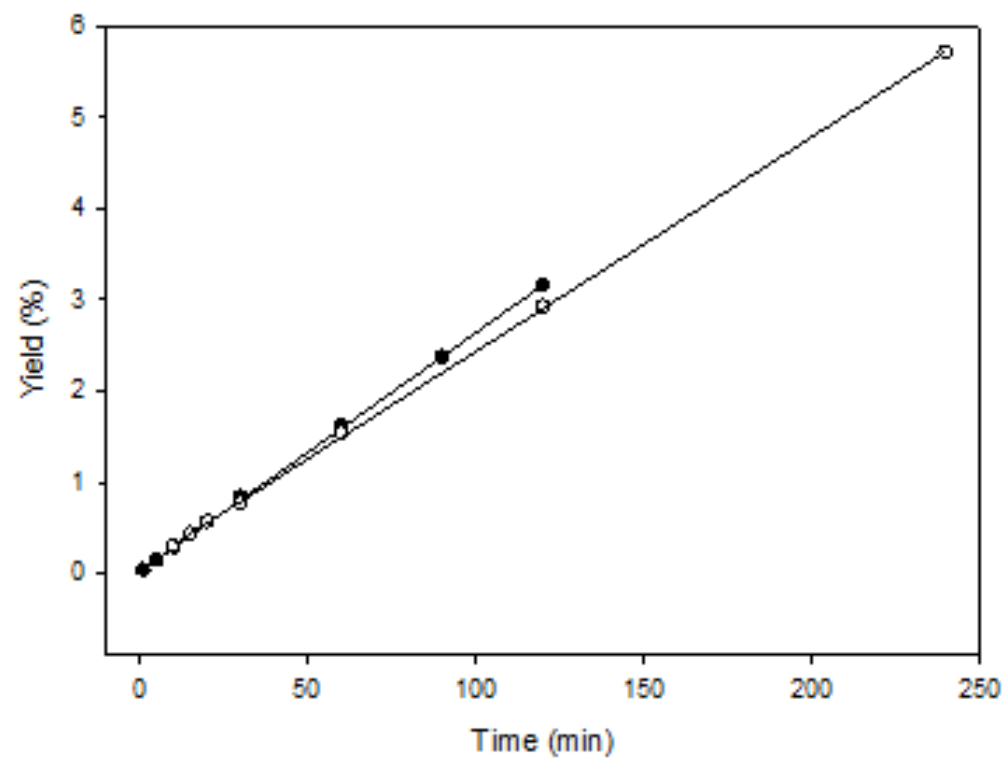

Appendice C: Kinetic curve adjustment to the second order model for baru almond oil extraction using: $(\mathbf{O})$ hexane and (O) isopropanol: ethanol (1:1).

\section{SOURCES OF FUNDING}

This research received no specific grant from any funding agency in the public, commercial, or not-for-profit sectors. 
Ana Luísa S. Souza, Julia S. Miranda, Rita C. S. Sousa, Bruno B. Vieira, and Jane S. R. Coimbra

\section{CONFLICT OF INTEREST}

The author have declared that no competing interests exist.

\section{ACKNOWLEDGMENT}

The authors are grateful for financial support from Brazilian funding agencies CNPq, CAPES and FAPEMIG.

\section{REFERENCES}

[1] Fernandes, D. C., Freitas, J. B., Czeder, L. P. and Naves, M. M. V. Nutritional composition and protein value of the baru (Dipteryx alata Vog.) almond from the Brazilian Savanna, Journal of the Science of Food and Agriculture, 2010, 90(10), 1650-1655.

[2] Cruz, K. S., Silva, M. A., Freitas, O. and Neves, V. A. Partial characterization of proteins from baru (Dipteryx alata Vog) seeds, Journal of the Science of Food and Agriculture 91, 2011, 2006-2012.

[3] Liu, G., Guasch-Ferre, M., Hu, Y., Li, Y., Hu, F. B., Rimm, E. B., Manson, J. E., Rexrode, K. and Sun Q. Nut consumption in relation to cardiovascular disease incidence and mortality among patients with diabetes mellitus, Circ. Res. 19, 2019, 1-18.

[4] Campidellia, M. L. L., Carneiro, J. D. S., Souza, E. C., Magalhães, M. L., Nunes, E. E. C., Faria, P. B., Franco, M. and Vilas Boas, E.V. B. Effects of the drying process on the fatty acid content, phenolic profile, tocopherols and antioxidant activity of baru almonds (Dipteryx alata Vog.), Grasas y Aceites 71 (1), 2020, 343.

[5] Siqueira, A. P. S. and Castro, C. F. S. Chemical quality of Baru almond (Dipteryx alata oil), Ciência Rural 46(10), 2016, 1865-1867.

[6] Borges, T. H., Malheiro, R., Souza, A. M., Casal, S. and Pereira, J. A. Microwave heating induces changes in the physicochemical properties of baru (Dipteryx alata Vog.) and soybean crude oils, European Journal of Lipid Science and Technology 117, 2014, 503-513.

[7] Fetzer, D. L., Cruz, P. N., Hamerski, F. and Corazza, M. L. Extraction of baru (Dipteryx alata vogel) seed oil using compressed solvents technology, The Journal of Supercritical Fluids 137, 2018, 23-33.

[8] Fernandes, D. C., Alves, A. M., Castro, G. S. F., Jordão Jr. A. A. and Naves, M. M. V. Effects of baru almond and brazil nut against hyperlipidemia and oxidative stress in vivo, Journal of Food Research 4 (4), 2015, 38-46.

[9] Schincaglia, R. M.; Cuppari, L.; Neri, H. F. S.; Cintra, D. E.; Sant'Ana, M. R.; Mota, J. F. Effects of baru almond oil (Dipteryx alata Vog.) supplementation on body composition, inflammation, oxidative stress, lipid profile, and plasma fatty acids of hemodialysis patients: a randomized, double-blind, placebo-controlled clinical trial, Complementary Therapies in Medicine 52, 2020, 102479.

[10] Marques, F., Neto, J., Cunha, L., Paula, J. and Bara, M. Identification of terpenes and phytosterols in Dipteryx alata (baru) oilseeds obtained through pressing, Revista Brasileira de Farmacognosia, 25, 2015, 522-525.

[11] Batista, A. C. F., Rodrigues, H. C., Pereira, N. R., Hernadez-Torrones, M. G., Viera, A. T. and Oliveira, M. F. Use of baru oil (Dipteryx alata Vog.) to produce biodiesel and study of the physical and chemical characteristics of biodiesel/petroleum diesel fuel blends, Chemistry and Technology of Fuels and Oils 48 (1), 2012, 13-16.

[12] Pineli, L. L. O., Carvalho, M. V., Aguiar, L. A., Oliveira, G. T., Celestino, S. M. C., Botelho, R. B. A. and Chiarello, M. D. Use of baru (Brazilian almond) waste from physical extraction of oil to produce flour and cookies, LWT Food Science and Technology 60(1), 2015, 50-55.

[13] Rincón-Cervera, M. A.; Galleguillos-Fernández, R.; González-Barriga, V.; Valenzuela, R.; Speisky, H.; Fuentes, J., Valenzuela, A. Fatty acid profile and bioactive compound extraction in purple viper's bugloss seed oil extracted with green solvents, Journal of the American Oil Chemists' Society 97, 2020, 319-327.

[14] Sousa, A. G. O., Fernandes, D. C., Alves A. M., Freitas, J. B. and Naves, M. M. V. Nutritional quality and protein value of exotic almonds and nut from the Brazilian Savanna compared to peanut, Food Research International. Barking 44, 2011, 2319-2325.

[15] Lira, F. F., Machado, W.; Santos, J. V. D.; Takashi, S. A., Guimarães, M. F. and Leal, A. C. Evaluation of the centesimal composition of macaúba fruits, Biochemistry and Biotechnology Reports 2, 2013, 17-20.

[16] Drummond, A. R. F., Gazineu, M. H., Almeida, L. and Souto, M. Methanol and ethanol as solvents in extraction of castor oil, Congress Brazilian Biodiesel Technology 1, 2006, 3-7. 
[17] Sawada, M. M.; Venâncio, L. L.; Toda, T. A.; Rodrigues, C. E. C. Effects of different alcoholic extraction conditions on soybeanoil yield, fatty acid composition and protein solubility of defatted meal, Food Res. Int. 62, 2014, 662-670.

[18] Baker, E. C. and Sullivan, D. A. Development of a pilot-plant process for the extraction of soy flakes with aqueous isopropyl-alcohol, Journal of the American Oil Chemists Society 60, 1983, 1271-1277.

[19] Seth, S., Agrawal, Y. C., Ghosh, P. K., Jayas, D. S. and Singh, B. P. N. Effect of moisture content on the quality of soybean oil and extracted by isopropyl alcohol and hexane, Food Bioprocess Technology 3, 2010, 121-127.

[20] Harris, W. D. and Hayward, J. W. Isopropanol as solvent for extraction of cottonseed oil. III. The use of recycling to effect solvent economy, Journal of the American Oil Chemists' Society 27, 1950, 273-275.

[21] Abdelmoez, W., Abdelfatah, R. and Tayeb, A. Extraction of cottonseed oil using subcritical water technology, American Institute of Chemical Engineers AIChE Journal 2011, 57, 2353-2359.

[22] Sayyar, S., Abidin, Z. Z., Yunus, R. and Muhammad, A. Extration of oil from jatropha seeds- optimization and kinects, American Journal of Applied Sciences 7, 2009, 1390-1395.

[23] Muhammad Hazwan, H., Azlina, C. M., Hasfalina,C.M., Zurina, Z.A. and Hisshamuddin, J. Optimization and kinetcs study of Gaharu oil extraction, Internationational Journal of Biological, Biomolecular, Agricultural, Food and Biotechnogical Engineering 7 (6), 2013, 454-457. 